\title{
Antioxidant effect of simvastatin throught oxidative imbalance caused by lisdexamfetamine dimesylate
}

\author{
GUILHERME A. EGER ${ }^{1}$, VINÍCIUS V. FERREIRA ${ }^{1}$, CAMILA R. BATISTA ${ }^{1}$, \\ HENRIQUE BONDE ${ }^{1}$, DANIELA D. DE LIMA ${ }^{2}$, ANGELA T.S. WYSE ${ }^{3}$, JÚLIA N. DA CRUZ ${ }^{4}$, \\ ANDRÉ F. RODRIGUES ${ }^{5}$, DÉBORA D. DAL MAGRO ${ }^{5}$ and JOSÉ G.P. DA CRUZ ${ }^{5}$ \\ ${ }^{1}$ Departamento de Medicina, Universidade Regional de Blumenau, Rua Antônio da \\ Veiga, 140, Bairro Victor Konder, 89012-900 Blumenau, SC, Brasil \\ ${ }^{2}$ Departamento de Medicina, Universidade da Região de Joinville, Rua Paulo \\ Malschitzki, 10, Bairro Bom Retiro, 89219-710 Joinville, SC, Brasil \\ ${ }^{3}$ Departamento de Bioquímica, Universidade Federal do Rio Grande do Sul, Rua Ramiro \\ Barcelos, 2600 Anexo, Bairro Santa Cecília, 90035-003 Porto Alegre, RS, Brasil \\ ${ }^{4}$ Instituto Dante Pazzanese de Cardiologia, Avenida Dr. Dante Pazzanese, 500, \\ Bairro Vila Mariana, 04012-909 São Paulo, SP, Brasil \\ ${ }^{5}$ Departamento de Ciências Naturais, Universidade Regional de Blumenau, Rua Antônio \\ da Veiga, 140, Bairro Victor Konder, 89012-900 Blumenau, SC, Brasil
}

Manuscript received on September 19, 2014; accepted for publication on June 16, 2015

\begin{abstract}
The present study aims to directly investigate the behavioral and antioxidant effects of simvastatin in a model of bipolar mania induced by lisdexamfetamine dimesylate. Wistar rats were treated for 30 days with simvastatin. On the 24th day after the start of treatment, each rat was administered lisdexamfetamine dimesylate for 7 days. The results suggest that simvastatin combined with lisdexamfetamine dimesylate induced a significant increased locomotion and lisdexamfetamine dimesylate administration causes an oxidative imbalance determined by an increment in lipid peroxidation, protein oxidation and alterations in the activities of antioxidant enzymes in brain areas; moreover, in the presence of simvastatin, most of these effects were prevented. These findings contribute to a better understanding of the critical roles of lisdexamfetamine dimesylate in the treatment of neuropsychiatric disorders, associated with increased oxidative stress and changes in antioxidant enzymatic defense. In view of the central role played by lisdexamfetamine dimesylate, the established antioxidant effect of simvastatin therapy is of major interest.
\end{abstract}

Key words: Amphetamine, Lisdexamfetamine dimesylate, Oxidative stress, Simvastatin.

\section{INTRODUCTION}

There is an emerging body of data indicating that major neuropsychiatric disorders, such as bipolar disorder and schizophrenia, are associated with increased oxidative stress and changes in antioxidant enzymatic defense (Dietrich-Muszalska and

Correspondence to: José Geraldo Pereira da Cruz

E-mail: cruzjgp@gmail.com
Kwiatkowska 2014, Rizzo et al. 2014). Reactive species are formed at physiological concentrations and degraded during normal aerobic metabolism in cells. However, increased or uncontrolled production of these species can result in oxidative damage to biomolecules, such as lipids, proteins and deoxyribonucleic acid, thereby disrupting cellular function and ultimately inducing apoptosis or necrosis (Garcia-Souza and Oliveira 2014). A large 
body of evidence indicates that repeated injections of amphetamine (AMPH) that induce hyperactivity in rodents are associated with increases in protein and lipid oxidative damage in putative brain areas, such as prefrontal cortex, hippocampus and striatum (Frey et al. 2006a, Andreazza et al. 2008, Riegel et al. 2009). Treatment with mood stabilizers may prevent and/or reverse AMPH, induced disruption in oxidative balance in these brain areas (Frey et al. 2006a).

Lisdexamfetamine dimesylate (LDX) is a novel pro-drug approved for the treatment of attention deficit hyperactivity disorder. It has a chemical designation of (2S)-2,6-diamino$\mathrm{N}$-[(1S)-1-methyl-2-phenylethyl] hexanamide dimethanesulfonate (Mattingly 2010). As a prodrug, it requires biotransformation to be converted to the active drug moiety, D-AMPH. D-AMPH, in turn, is the dextrorotary stereoisomer of the AMPH molecule and is approximately twice as potent as methylphenidate. In the LDX molecule, the amino acid L-lysine is covalently bound to D-AMPH (the active portion of the drug) through a peptide bond. Trypsin, which is found in abundance in the gastrointestinal tract, is believed to be the primary enzyme that converts LDX to D-AMPH following oral administration (Rowley et al. 2012). AMPH is known to have a high potential for abuse (Najib 2012). Because of the significant risk of abuse related to this drug, the acquisition of AMPH is under strict regulatory policies in several countries, which limits the availability of this compound for use in research. The unique pharmacokinetic properties of LDX may explain the somewhat lower abuse liability of this compound when compared to AMPH.

Statins are drugs primarily used to control cholesterol disorders and prevent cardiovascular disease. They inhibit 3-hydroxy-3-methylglutarylcoenzyme-A reductase, the rate-limiting enzyme in cholesterol biosynthesis. Since statins have relatively few side effects, they have been recognized as useful medicine to ameliorate neurodegenerative disorders. Current studies on the applications of statins have demonstrated their neuroprotective and clinical significance among neurodegenerative diseases like cerebral ischemic stroke, vascular dementia, Alzheimer's disease, and Parkinson's disease, though the neuroprotective mechanisms are not completely understood (Vance 2012, Barone et al. 2014, Moon et al. 2014). There is a growing recognition that statins have pleiotropic effects beyond lowering cholesterol levels (Santos et al. 2012, Camargo et al. 2013).

Therefore, the purpose of this study was to investigate the effects of sub-chronic administration of simvastatin on the effects provoked by LDX on the spontaneous locomotion of rats submitted to open-field test, on thiobarbituric acid-reactive substances (TBARS) levels and protein carbonyl content, as well as, and on the activities of antioxidant enzymes catalase (CAT), glutathione peroxidase (GSH-Px) and superoxide dismutase (SOD) in the cerebellum, hippocampus and cerebral cortex of rats.

\section{MATERIALS AND METHODS}

SUBJECTS

A total of 72 male genetically heterogeneous albino Wistar rats (Rattus norvegicus), 2 months old and weighing 250 to $280 \mathrm{~g}$, were obtained from the animal house of the Universidade Regional de Blumenau. After arrival in the vivarium of the laboratory, these animals were housed in groups of five per opaque plastic cage $(50 \times 30 \times 15 \mathrm{~cm})$ with wood shaving bedding and wire mesh tops. They were housed under a standard (12/12 h light/ dark; cycle lights on at 7:00 AM), in a temperaturecontrolled environment $\left(23 \pm 1{ }^{\circ} \mathrm{C}\right)$, with a $50 \mathrm{~dB}$ background sound level, and $55 \pm 10 \%$ relative humidity. During the light and dark phases, the rats were exposed to light intensities of approximately 325 and 0.025 lux, respectively. These lux values were chosen because they were the light 
intensities that were closest to natural daytime and nighttime light in our laboratory. During the entire experimental period, the animals received commercial chow for rodents (Nuvital ${ }^{\circledR}$, Paraná, Brazil) and filtered tap water ad libitum. The animals were acclimated to the animal housing facilities for at least 1 week before the experiments began. The experiments were performed in compliance with the recommendations of the Brazilian Society of Neuroscience and Behavior, which are based on the United States National Institutes of Health Guide for Care and Use of Laboratory Animals. All experiments were approved by the local ethical committee of Universidade Regional de Blumenau (Protocol 005/13).

\section{EXPERIMENTAL PROTOCOLS}

The rats were orally administered simvastatin (1 or $10 \mathrm{mg} / \mathrm{kg} /$ day by oral gavage, Zocor ${ }^{\circledR}$; Merck KGaA, Darmstadt, Germany) for 30 days (Santos et al. 2012). On the $24^{\text {th }}$ day of treatment with simvastatin, groups were randomized with 8 rats per group and orally administered LDX for 7 days $\left(10\right.$ or $30 \mathrm{mg} / \mathrm{kg} /$ day; Vyvanse ${ }^{\circledR}$; Shire, USA) (Macêdo et al. 2013). The interval between the administration of simvastatin and LDX was 30 minutes. Two hours after the last administration of LDX, rats were submitted to behavioral test. Control group received saline.

\section{TISSUE PREPARATION}

Immediately after the behavioral test, animals were killed by decapitation and the cerebellum, hippocampus and cerebral cortex were removed and dissected on an ice-cooled glass plate. Time elapsed between decapitation and dissection was less than 1 minute. After dissection, the cerebral structures were homogenized with appropriate buffer for each assay with a Potter-Elvehjem glass homogenizer. The maximum period between homogenate preparation and enzyme analysis was always less than 3 days. All procedures were carried out at $0-4{ }^{\circ} \mathrm{C}$.

\section{OPEN-FIELD TEST}

The open-field consisted of a black circular box (75 $\mathrm{cm}$ in diameter and $40 \mathrm{~cm}$ high). The open-field had two concentric circles $(45.7 \mathrm{~cm}$ and $15.2 \mathrm{~cm}$ diameter) drawn on the floor. In addition, six lines radiating $60^{\circ}$ from the center circle divided the field into sixths. The center circle was not divided, for a total of thirteen sectors. The test arena was divided into central and peripheral zones. Each rat was placed in the central area and was allowed to explore for 5 minutes. After the 5 minutes test, the rats were returned to the home cages, and the open field was cleaned thoroughly and allowed to dry between tests. The following parameters were recorded: time the movement of the animal between parts spent in the central or peripheral zones of the apparatus (ambulation); the number of lines crossed - all 4 paws required crossing a line for a count to occur (locomotor frequency); time and frequency of rearing (the rat stood on its hind paws with its body at greater than a $45^{\circ}$ angle to the floor). These data were used to calculate percentage of time spent in the behavior (100 x behavior/300). The ambulation time and frequency of lines crossed was determined as a measure of activity. Exploration behavior in the open-field has also been used as a measure of defensive behavior, where increased line rearing responses are suggestive of a decrease in defensive behaviors (Santos et al. 2012, Camargo et al. 2013).

THIOBARBITURIC ACID REACTIVE SUBSTANCES (TBARS)

TBARS was determined according to the method described by Ohkawa et al. (1979). TBARS measures malondialdehyde, a product of lipoperoxidation caused mainly by free hydroxyl radicals. Briefly, plasma in $1.15 \% \mathrm{KCl}$ were mixed with $20 \%$ trichloroacetic acid and $0.8 \%$ thiobarbituric acid and heated in a boiling water bath for 60 minutes. TBARS were determined by the absorbance at $535 \mathrm{~nm}$. Calibration curve was performed using 1,1,3,3-tetramethoxypropane 
and each curve point was subjected to the same treatment as that of the supernatants. TBARS was calculated as nanomole of malondialdehyde formed per milligram of protein.

\section{PROTEIN CARBONYL CONTENT}

Oxidatively modified proteins present an enhancement of carbonyl content (Stadtman and Levine 2003). In this study, protein carbonyl content was assayed by a method based on the reaction of protein carbonyls with dinitrophenylhydrazine forming dinitrophenylhydrazone, a yellow compound, measured spectrophotometrically at 370 nm (Reznick and Packer 1994). Briefly, $100 \mu 1$ of homogenatewere added to plastic tubes containing $400 \mu 1$ of $10 \mathrm{mM}$ dinitrophenylhydrazine (prepared in $2 \mathrm{M} \mathrm{HCl}$ ). This was kept in the dark for $1 \mathrm{~h}$ and vortexed each 15 minutes. After that, $500 \mu \mathrm{l}$ of $20 \%$ trichloroacetic acid were added to each tube. The mixture was vortexed and centrifuged at $20.000 \mathrm{~g}$ for 3 minutes. The supernatant obtained was discarded. The pellet was washed with 1 $\mathrm{ml}$ ethanol/ethyl acetate $(1: 1 \mathrm{v} / \mathrm{v})$, vortexed, and centrifuged at $20.000 \mathrm{~g}$ for 3 minutes. The supernatant was discarded and the pellet resuspended in $600 \mu 1$ of $6 \mathrm{M}$ guanidine (prepared in a $20 \mathrm{mM}$ potassium phosphate solution $\mathrm{pH} 2.3$ ). The sample was vortexed and incubated at $60{ }^{\circ} \mathrm{C}$ for 15 minutes. After that, it was centrifuged at 20.000 $\mathrm{g}$ for 3 minutes and the absorbance was measured at $370 \mathrm{~nm}$ (UV) in a quartz cuvette. Results were represented as protein carbonyl content (nmol/mg protein).

\section{CATALASE ASSAY (CAT)}

CAT activity was assayed by the method of Aebi (1984). $\mathrm{H}_{2} \mathrm{O}_{2}$ disappearance was continuously monitored with a spectrophotometer at $240 \mathrm{~nm}$ for $90 \mathrm{~s}$. One unit of the enzyme is defined as $1 \mathrm{mmol}$ of hydrogen peroxide consumed per minute and the specific activity is reported as units per mg protein.

\section{GLUTATHIONE PEROXIDASE (GSH-PX)}

GSH-Px activity was measured by the method of Wendel (1981) except for the concentration of NADPH, which was adjusted to $0.1 \mathrm{mM}$ after previous tests performed in our laboratory. Tertbutylhydroperoxide was used as substrate. NADPH disappearance was continuously monitored with a spectrophotometer at $340 \mathrm{~nm}$ for 4 minutes. One GSH-Px unit is defined as $1 \mathrm{mmol}$ of NADPH consumed per minute and specific activity is reported as units per mg protein.

\section{SUPEROXIDE DISMUTASE (SOD) ASSAY}

This method for the assay of SOD activity is based on the capacity of pyrogallol to autoxidize, a process highly dependent on $\mathrm{O}_{2}$, which is a substrate for SOD (Flohé and Otting 1984). The inhibition of autoxidation of this compound occurs in the presence of SOD, whose activity can be then indirectly assayed spectrophotometrically at $420 \mathrm{~nm}$. A calibration curve was performed with purified SOD as standard, in order to calculate the activity of SOD present in the samples. The results were reported as units/mg protein.

PROTEIN DETERMINATION

Protein was measured by the Lowry et al. (1951), using serum bovine albumin as standard.

\section{STATISTICAL ANALYSIS}

For behavioral tests, the means were compared using analysis of variance (ANOVA), followed by the Newman-Keuls multiple comparison test. For biochemical analyses, data were analyzed by ANOVA followed by the Duncan multiple range test when the F-test was significant. All analyses were performed using the Statistical Package for the Social Sciences (SPSS) software in a PC compatible computer. Values of $p<0.05$ were considered to be significant. 


\section{RESULTS}

\section{OPEN-FIELD TEST}

ANOVA revealed significant differences between groups for percent ambulation/ outside zone time of the open-field test $(F=13.702 ; p<0.001$; Figure 1a). The rats administered either $30 \mathrm{mg} / \mathrm{kg}$ of LDX $(\mathrm{p}<0.001)$; group orally administered $1 \mathrm{mg} /$ $\mathrm{kg}$ /day of simvastatin combined with $30 \mathrm{mg} / \mathrm{kg}$ of LDX $(p<0.001)$, and $10 \mathrm{mg} / \mathrm{kg} /$ day of simvastatin combined with 10 or $30 \mathrm{mg} / \mathrm{kg}$ of LDX ( $<<0.001$ ), showed increased percent ambulation/outside zone time when compared with the vehicle group. In addition, simvastatin at the dose of $1 \mathrm{mg} / \mathrm{kg}$ /day combined with $30 \mathrm{mg} / \mathrm{kg}$ of LDX $(\mathrm{p}<0.001)$, and simvastatin at the dose $10 \mathrm{mg} / \mathrm{kg} /$ day combined with 10 or $30 \mathrm{mg} / \mathrm{kg}$ of LDX ( $<0.001)$, revealed significant increased between groups for percent ambulation/interior zone time of the open-field test when compared with the vehicle group $(\mathrm{F}=$ 14.804; $\mathrm{p}<0.001$; Figure 1b). Data analysis reveals significant differences between groups for locomotor frequency/outside zone of the open-field test $(\mathrm{F}=$ 7.374; $\mathrm{p}<0.001$; Figure 1c). The rats administered either $30 \mathrm{mg} / \mathrm{kg}$ of LDX $(\mathrm{p}<0.01)$; group orally administered $1 \mathrm{mg} / \mathrm{kg} /$ day of simvastatin combined with $30 \mathrm{mg} / \mathrm{kg}$ of LDX ( $<<0.05)$, and $10 \mathrm{mg} / \mathrm{kg} /$ day of simvastatin combined with 10 or $30 \mathrm{mg} / \mathrm{kg}$ of LDX $(p<0.01$ and $p<0.001$, respectively), showed increased locomotor frequency/outside zone when compared with the vehicle group. In addition, simvastatin at the dose of $1 \mathrm{mg} / \mathrm{kg} /$ day combined with $30 \mathrm{mg} / \mathrm{kg}$ of LDX $(\mathrm{p}<0.05)$, and simvastatin at the dose $10 \mathrm{mg} / \mathrm{kg} /$ day combined with 10 or $30 \mathrm{mg} /$ $\mathrm{kg}$ of LDX $(\mathrm{p}<0.05)$, revealed significant increased between groups for locomotor frequency/interior zone of the open-field test when compared with the vehicle group $(\mathrm{F}=4.509 ; \mathrm{p}<0.001$; Figure $1 \mathrm{~d})$.

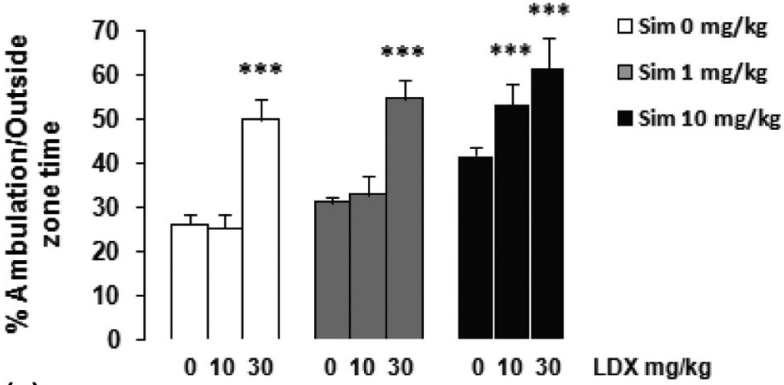

(a)

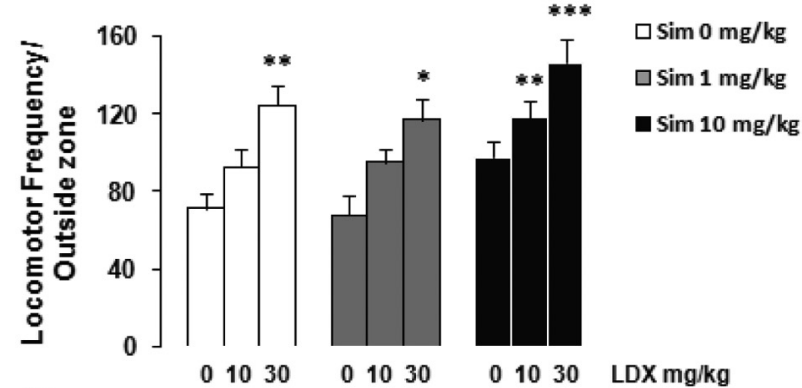

(c)

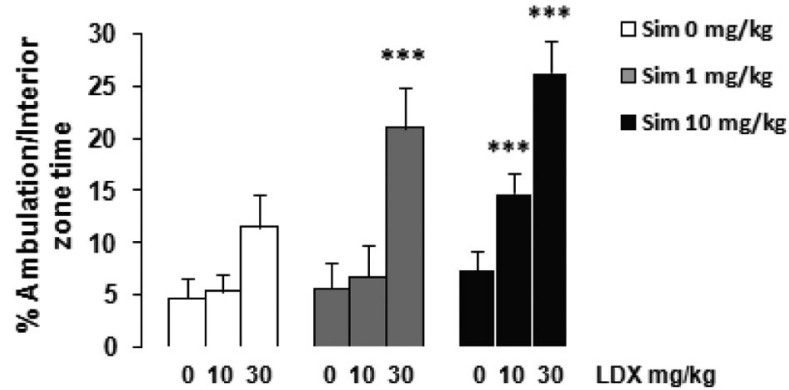

(b)

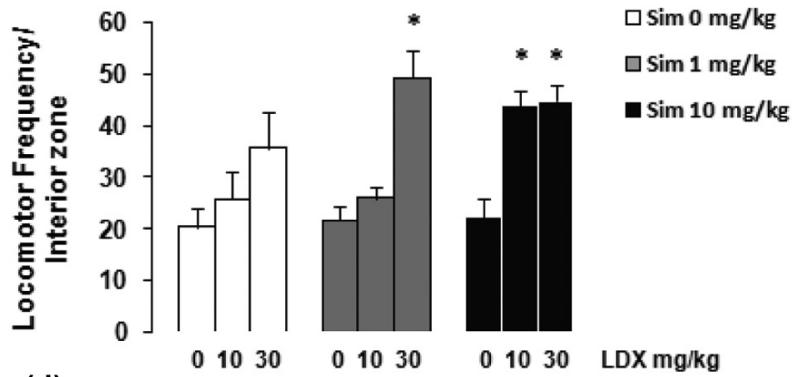

(d)

Figure 1 - Behavioral responses in the open-field of sub-chronic simvastatin (Sim) treatment combined with lisdexamfetamine dimesylate (LDX) in rats: (a) percent ambulation/outside zone time; (b) percent ambulation/interior zone time; (c) locomotor frequency/outside zone, and (d) locomotor frequency/interior zone. Bars represent the means for each group and the vertical lines represent the standard errors of the means. Significant changes between intervention and vehicle group were observed $(\mathrm{n}=8$; $* \mathrm{p}<0.05 ; * * \mathrm{p}<0.01 ; * * * \mathrm{p}<0.001 ;$ ANOVA followed by Newman-Keuls test). 
THIOBARBITURIC ACID REACTIVE SUBSTANCES (TBARS)

ANOVA revealed significant differences between groups for the content of TBARS in the cerebellum $(\mathrm{F}=28.278 ; \mathrm{p}<0.001 ;$ Figure $2 \mathrm{a})$, hippocampus ( $\mathrm{F}$ $=55.263 ; \mathrm{p}<0.001 ;$ Figure $2 \mathrm{~b})$ and cerebral cortex $(F=20.188 ; p<0.001 ;$ Figure $2 c)$ of rats. Repeated LDX (10 or $30 \mathrm{mg} / \mathrm{kg}$ ) exposure increased TBARS generation. Simvastatin $1 \mathrm{mg} / \mathrm{kg} /$ day prevented the enhanced caused by LDX at $10 \mathrm{mg} / \mathrm{kg}$ and just simvastatin at the dose of $10 \mathrm{mg} / \mathrm{kg} /$ day prevented the increased caused by LDX $30 \mathrm{mg} / \mathrm{kg}$ when compared with the vehicle group.

\section{PROTEIN CARBONYL CONTENT}

Data analysis reveals significant differences between groups for protein carbonyl content in the cerebellum $(F=23.522 ; p<0.001$; Figure $3 a)$, hippocampus $(\mathrm{F}=26.235 ; \mathrm{p}<0.001 ;$ Figure $3 \mathrm{~b})$ and cerebral cortex $(F=5.520 ; p<0.001$; Figure $3 c)$ of rats. The rats administered either $30 \mathrm{mg} / \mathrm{kg}$ of LDX showed increased protein carbonyl. Additionally, sub-chronic administration of simvastatin, just at the dose of $10 \mathrm{mg} / \mathrm{kg}$ prevented such effects.

CATALASE ASSAY (CAT)

Figure 4a shows that LDX (10 or $30 \mathrm{mg} / \mathrm{kg}$ ) did not alter CAT activity in the cerebellum of rats $(F=0.2523 ; p>0.05)$, when compared with the vehicle group. Figure $4 \mathrm{~b}$ shows that LDX $30 \mathrm{mg} / \mathrm{kg}$ decreased CAT activity in the hippocampus of rats, while simvastatin (1 or $10 \mathrm{mg} / \mathrm{kg} /$ day) prevented this reduction caused by LDX $(F=13.146 ; p<0.001)$, when compared with the vehicle group. In addition, Figure $4 \mathrm{c}$ shows that LDX (10 and $30 \mathrm{mg} / \mathrm{kg}$ ) decreased CAT activity in the cerebral cortex of rats, simvastatin $(1 \mathrm{mg} / \mathrm{kg} /$ day $)$ prevented the decreased caused by LDX $10 \mathrm{mg} / \mathrm{kg}$ and just simvastatin at the dose of $10 \mathrm{mg} / \mathrm{kg} /$ day prevented the decreased caused by LDX $30 \mathrm{mg} / \mathrm{kg}(\mathrm{F}=28.228 ; \mathrm{p}<0.001)$, when compared with the vehicle group.
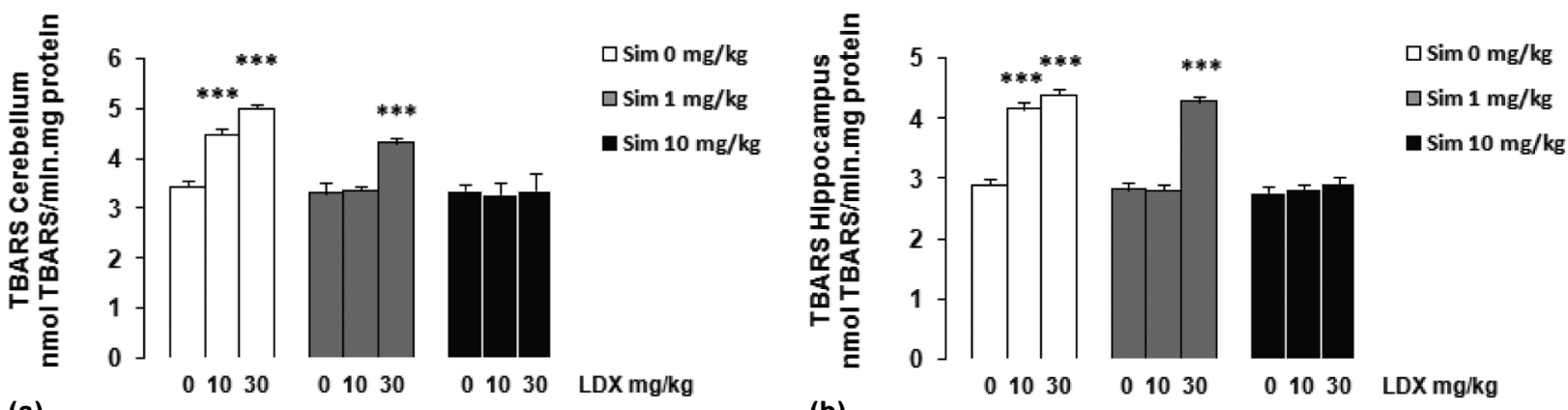

(a)

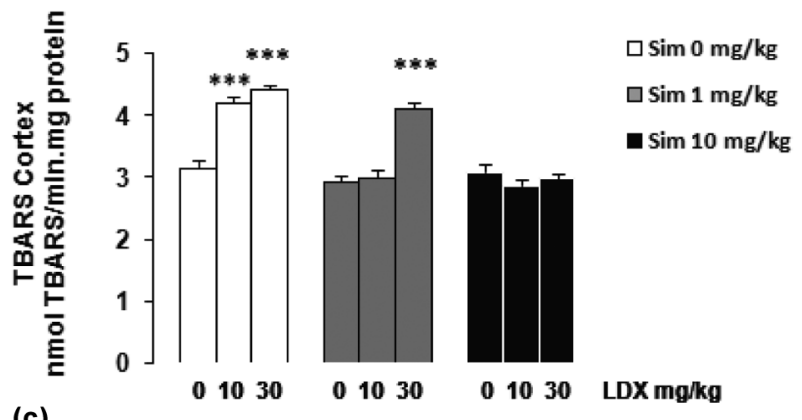

Figure 2 - Effects of simvastatin (Sim) administration in the presence or absence of lisdexamfetamine dimesylate (LDX) on thiobarbituric acid reactive substances (TBARS): (a) cerebellum; (b) hippocampus, and (c) cerebral cortex. TBARS is expressed as nmol of malondialdehyde per mg protein. Data are mean \pm SD for 8 independent experiments (animals) performed in duplicate. Different from control, $* * * p<0.001$ (Duncan multiple range test). 

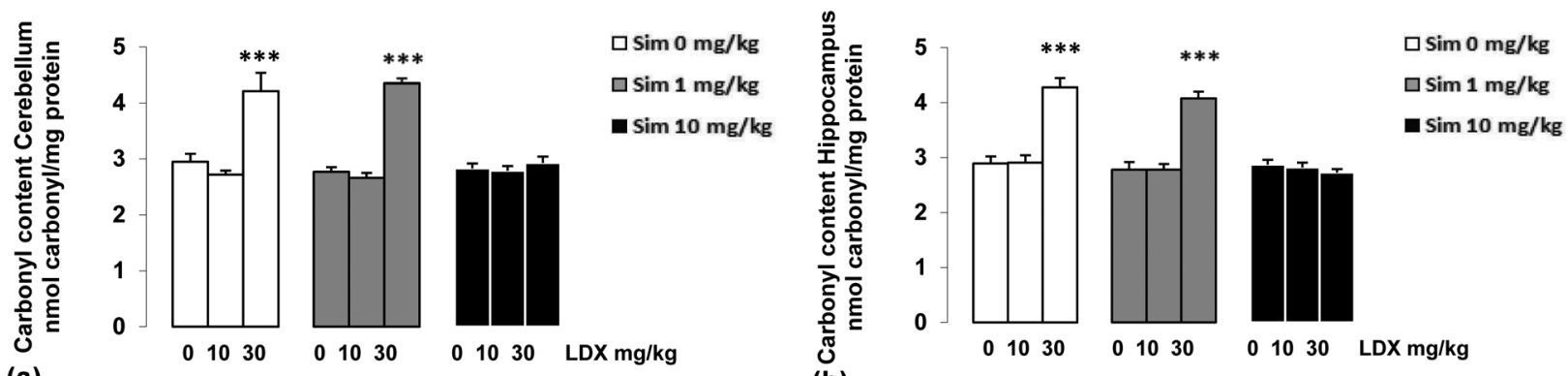
(a)
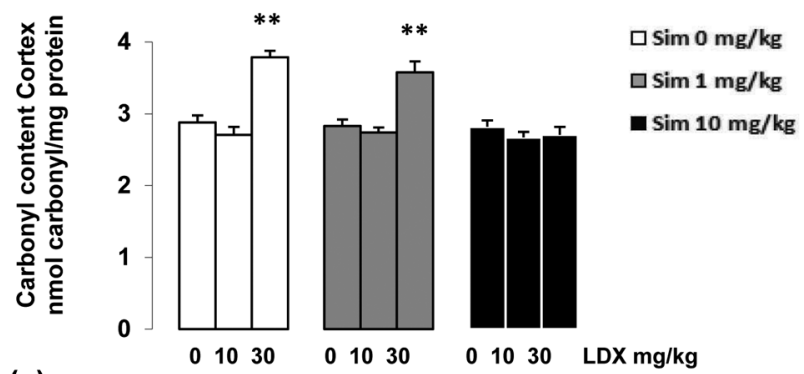

(c)

Figure 3 - Effects of simvastatin (Sim) administration in the presence or absence of lisdexamfetamine dimesylate (LDX) on carbonyl content: (a) cerebellum; (b) hippocampus, and (c) cerebral cortex. Carbonyl content is expressed as nmol of carbonyl per $\mathrm{mg}$ protein. Data are mean $\pm \mathrm{SD}$ for 8 independent experiments (animals) performed in duplicate. Different from control, $* * \mathrm{p}<0.01$ and $* * * \mathrm{p}<0.001$ (Duncan multiple range test).
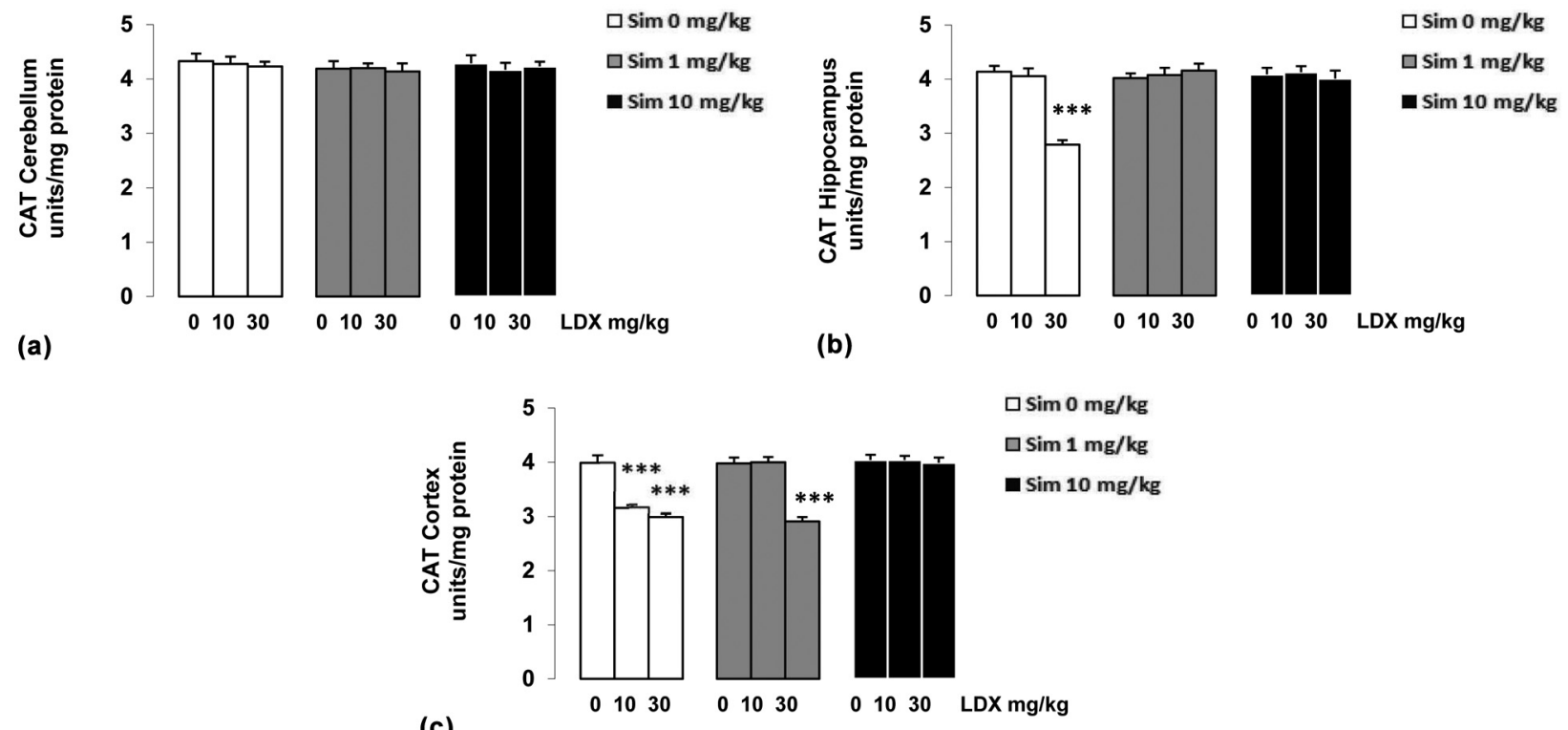

Figure 4 - Effects of simvastatin (Sim) administration in the presence or absence of lisdexamfetamine dimesylate (LDX) on catalase (CAT) activity: (a) cerebellum; (b) hippocampus, and (c) cerebral cortex. Enzyme activity is expressed as units per mg protein. One catalase (CAT) unit is defined as 1 mmol of $\mathrm{H}_{2} \mathrm{O}_{2}$ consumed per minute. Data are mean \pm SD for 8 independent experiments (animals) performed in duplicate. Different from control, $* * * p<0.001$ (Duncan multiple range test). 


\section{GLUTATHIONE PEROXIDASE (GSH-PX)}

In relation to the GSH-Px activity, Figure 5a shows that LDX (10 and $30 \mathrm{mg} / \mathrm{kg}$ ) did note alter the enzyme activity in the cerebellum of rats $(\mathrm{F}=$ $0.1191 ; p>0.05)$, when compared with the vehicle group. By the other hand, Figure $5 \mathrm{~b}$ shows that LDX $30 \mathrm{mg} / \mathrm{kg}$ increased the enzyme activity in the hippocampus of rats and simvastatin $10 \mathrm{mg} / \mathrm{kg} /$ day prevented this effect $(F=30.390 ; p<0.001)$, when compared with the vehicle group. In addition, Figure $5 \mathrm{c}$ shows that LDX $30 \mathrm{mg} / \mathrm{kg}$ increased GSH-Px activity in the cerebral cortex of rats and simvastatin 1 or $10 \mathrm{mg} / \mathrm{kg} /$ day prevented this effect ( $F=6.456 ; p<0.001$ ), when compared with the vehicle group.

\section{SUPEROXIDE DISMUTASE (SOD) ASSAY}

Regarding to SOD activity, Figure 6 a shows that LDX $30 \mathrm{mg} / \mathrm{kg}$ significantly decreased SOD activity in the cerebellum of rats and simvastatin 10 $\mathrm{mg} / \mathrm{kg} /$ day prevented this decreased $(\mathrm{F}=32.067$; $\mathrm{p}<0.001$ ), when compared with the vehicle group. Figure $6 \mathrm{~b}$ shows that LDX $30 \mathrm{mg} / \mathrm{kg}$ enhanced SOD activity in the hippocampus of rats, while simvastatin 1 or $10 \mathrm{mg} / \mathrm{kg} /$ day prevented this effect ( $F=13.273 ; p<0.001)$. As can be seem in Figure 6c, LDX 10 or $30 \mathrm{mg} / \mathrm{kg}$ increased SOD activity in the cerebral cortex of rats, simvastatin $1 \mathrm{mg} / \mathrm{kg}$ / day prevented the increased caused by LDX $10 \mathrm{mg} /$ $\mathrm{kg}$ and simvastatin $10 \mathrm{mg} / \mathrm{kg} /$ day prevented just the increased caused by LDX $30 \mathrm{mg} / \mathrm{kg}$ on SOD activity $(\mathrm{F}=33.265 ; \mathrm{p}<0.001)$, when compared with the vehicle group. Post hoc analyses showed that simvastatin 1 and $10 \mathrm{mg} / \mathrm{kg} /$ day per se did not alter these parameters.

\section{DISCUSSION}

Results showed that LDX (30 mg/kg) increased ambulation/outside zone time in the open-field. Additionally, co-treatment with LDX (10 or 30 $\mathrm{mg} / \mathrm{kg})$ and simvastatin $(10 \mathrm{mg} / \mathrm{kg} /$ day $)$ increased ambulation/outside and interior zone time. Similar
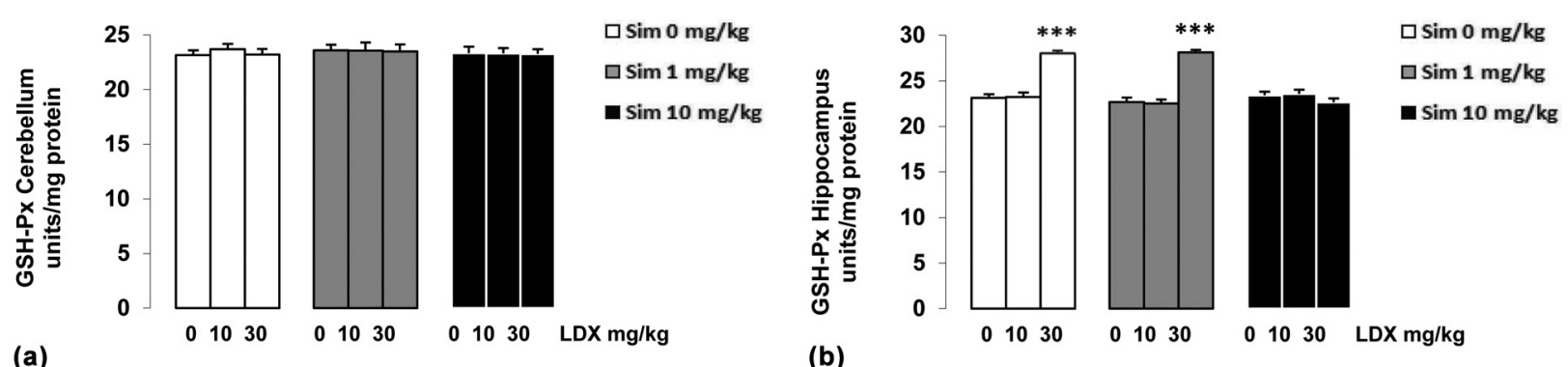

(a)

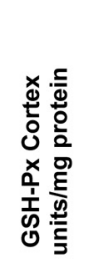

(c)
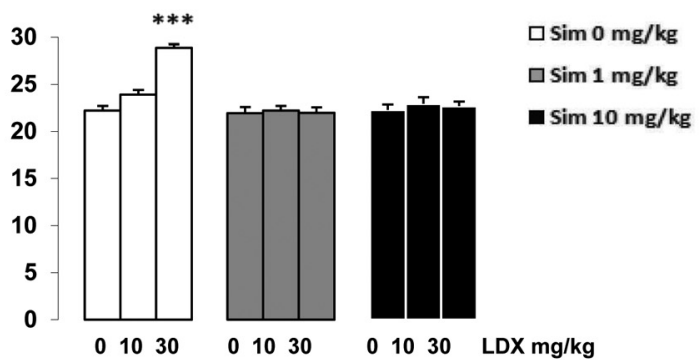

Figure 5 - Effects of simvastatin (Sim) administration in the presence or absence of lisdexamfetamine dimesylate (LDX) on glutathione peroxidase (GSH-Px) activity: (a) cerebellum; (b) hippocampus, and (c) cerebral cortex. Enzyme activity is expressed as units per mg protein. One glutathione peroxidase (GSH-Px) unit is defined as $1 \mathrm{mmol}$ of NADPH consumed per minute. Data are mean \pm SD for 8 independent experiments (animals) performed in duplicate. Different from control, $* * * \mathrm{p}<0.001$ (Duncan multiple range test). 

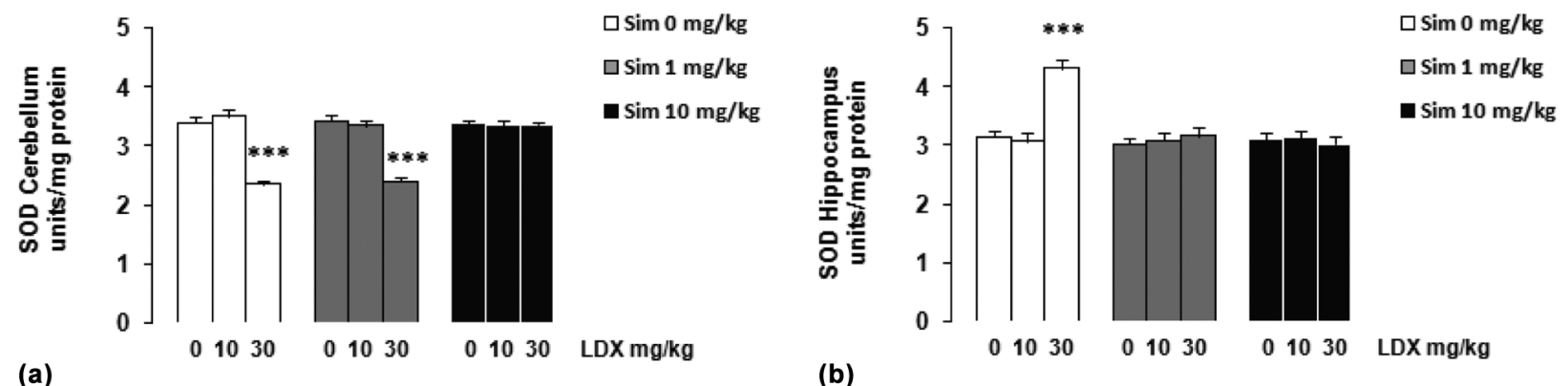

(b)

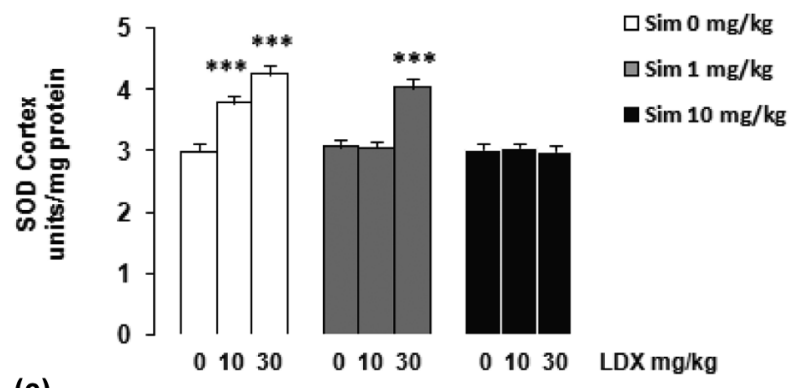

(c)

Figure 6 - Effects of simvastatin (Sim) administration in the presence or absence of lisdexamfetamine dimesylate (LDX) on superoxide dismutase (SOD) activity: (a) cerebellum; (b) hippocampus, and (c) cerebral cortex. Enzyme activity is expressed as units per mg protein. One SOD unit is defined as the amount of SOD necessary to inhibit $50 \%$ of pyrogallol autoxidation. Data are mean $\pm \mathrm{SD}$ for 8 independent experiments (animals) performed in duplicate. Different from control, $* * * \mathrm{p}<0.001$ (Duncan multiple range test).

results were obtained in the number of lines crossed, indicating a synergistic effect of combination drug administration. The treatment of male SpragueDawley rats with simvastatin at a high dose $(10 \mathrm{mg} /$ $\mathrm{kg} /$ day) produced a significantly longer traveled distance and higher average velocity in an openfield arena, suggesting hyperlocomotive activity. A possible mechanism mediating these effects may involve modulation of N-methyl-D-aspartate receptor (NMDAR) (Wang et al. 2009). The present study is consistent with previous observation in which simvastatin upregulated NMDAR in the rat brain, and further validates our proposal that simvastatin may exhibit NMDA antagonist-like effect, enhanced the locomotor effects of AMPH in rats (Kreipke and Walker 2004, Wang et al. 2009).

The persistent molecular effects of AMPH exposure produce behavioral sensitization that is revealed by increased locomotion with repeated exposure to the drug (Robinson and Becker 1986).
However, the mechanism by which systemically delivered NMDAR antagonists block sensitization is unclear. A few studies have used cleaner, competitive NMDAR antagonists in examining AMPH-induced sensitization. For example, Wolf et al. (1995) used CGS19755 and found a "clean block" of AMPH sensitization - i.e., stereotyped and locomotor behavior did not increase with repeated administration in rats co-administered CGS19755 with AMPH. However, CGS19755 dramatically altered the acute locomotor response to AMPH, in particular the time course of the drug response. This difference in time course makes a later sensitization challenge test difficult to interpret. It seems that most competitive NMDAR antagonists interfere with the acute behavioral response to AMPH; CPP, CGS19755, and AP5 have all been shown to alter the acute responses to AMPH (Wolf et al. 1995, Cador et al. 1999, Battisti et al. 2000). These findings highlight the need for more studies 
using selective NMDAR antagonists and more attention to the effect of NMDAR antagonism on acute AMPH induced behaviors.

Recent studies have shown that 3-hydroxy-3methylglutaryl coenzyme A reductase inhibitors, statins, may have beneficial pleiotropic effects in some pathological conditions independent of lipidlowering effects (Mohammadi et al. 2013, Moon et al. 2014). Statins generally have been widely used to reduce cholesterol levels, and recently, they have attracted even more attention due to their antioxidant, anti-inflammatory, anti-ischemic, and blood-brain barrier repairing effect (Mohammadi et al. 2013, Davaro et al. 2014, Malfitano et al. 2014, Uekawa et al. 2014).

The LDX and/or simvastatin increase the extracellular concentration of monoamines, such as dopamine, leading to increased dopamine transmission (Rowley et al. 2012). The neurotoxicity observed upon exposure to AMPH may be due to dopamine-induced oxidative stress. Although the exact mechanisms of AMPH induced neurotoxicity are unknown, in the present study we investigated the effects of sub-chronic administration of simvastatin on the effects provoked by LDX about TBARS levels and protein carbonyl content, as well as, and on the activities of antioxidant enzymes CAT, GSH-Px and SOD in the cerebellum, hippocampus and cerebral cortex of rats.

Regarding the effects of sub-chronic administration of simvastatin on the effects provoked by LDX on TBARS levels and protein carbonyl content in brain, LDX enhanced TBARS levels in the cerebellum, hippocampus and cerebral cortex (10 and $30 \mathrm{mg} / \mathrm{kg})$ of rats. Simvastatin (10 $\mathrm{mg} / \mathrm{kg} /$ day) prevented the enhanced caused by LDX in the brain of rats. Towards protein carbonyl content, LDX (30 mg/kg) enhanced protein markers of oxidative stress in the cerebellum, hippocampus and cerebral cortex. Additionally, sub-chronic administration of simvastatin, just at the dose of $10 \mathrm{mg} / \mathrm{kg} /$ day prevented such effects. These results suggest that LDX induces lipid peroxidation and protein oxidation in cerebrum. Furthermore, these effects were prevented by simvastatin, showing an antioxidant property.

Oxidative stress is defined as a persistent imbalance between antioxidants and pro-oxidants processes in favor of the latter. The result of this phenomenon is the excessive production of free radicals, the reactive oxygen species (ROS). The brain is particularly vulnerable to ROS production because it metabolizes $20 \%$ of total body oxygen and has a limited amount of antioxidant capacity (Floyd 1999). In situations where the generation of free radicals exceeds the capacity of antioxidant defence, oxidative stress may lead to membrane degradation, cellular dysfunction and apoptosis. AMPH can enhance ROS formation through several pathways, for example, through autooxidation of dopamine with the formation of highly reactive quinines, direct inhibition of mitochondrial electron transport chain complexes and increased glutamate release (Sonsalla et al. 1989, Berman and Hastings 1999, Burrows et al. 2000). One reliable index of oxidative stress to proteins involves the measurement of protein carbonyl formation, resulting from the reaction of ROS with various protein side groups including lysine and arginine (Temple et al. 2006). Protein carbonyl measurements offer certain advantages over TBARS because of its lack of interference with other non-protein substances and are a more dependable measure of protein oxidative stress (Levine et al. 1990). Therefore, we have simultaneously measured TBARS and protein carbonyls to provide a more complete picture of the damage to proteins and lipids produced by ROS following LDX treatment. According to Gluck et al. (2001), AMPH promote timedependent and brain region-selective elevation of protein carbonyls and TBARS in mice. More specifically, the authors demonstrated elevated TBARS and protein carbonyl levels at 4 and $24 \mathrm{~h}$ 
after $40 \mathrm{mg} / \mathrm{kg}$ of AMPH in striatum and at $24 \mathrm{~h}$ in hippocampus. In this context, Frey et al. (2006b) observed that repeated (one injection daily for 7 days), but not a single injection of AMPH-induced lipid peroxidation in striatum, hippocampus, and cortex in rats. They also demonstrated that repeated AMPH exposure increased protein oxidation in all brain regions, and this effect persisted for, at least, $6 \mathrm{~h}$ after the last injection in striatum and cortex, but not in hippocampus.

Regarding the effects of sub-chronic administration of simvastatin on the effects provoked by LDX on the activities of antioxidant enzymes CAT, GSH-Px and SOD in cerebrum of rats. Post hoc analyses showed that simvastatin 1 and $10 \mathrm{mg} / \mathrm{kg}$ per se did not alter the enzymes activities. Additionally, statistical analyses showed that LDX (10 and $30 \mathrm{mg} / \mathrm{kg}$ ) did not alter CAT and GSH-Px activities in the cerebellum of rats. By the other hand, LDX $30 \mathrm{mg} / \mathrm{kg}$ decreased SOD activity in the cerebellum and this effect was prevented by simvastatin $10 \mathrm{mg} / \mathrm{kg} /$ day. In the hippocampus of rats, LDX $30 \mathrm{mg} / \mathrm{kg}$ decreased CAT activity and enhanced SOD and GSH-Px activities. Sub-chronic administration of simvastatin 1 or $10 \mathrm{mg} / \mathrm{kg} /$ day prevented the decreased of CAT activity and the increased of SOD and GSH-Px activities and just at the dose of $10 \mathrm{mg} / \mathrm{kg} /$ day. Finally, in the cerebral cortex of rats, LDX decreased CAT (10 and $30 \mathrm{mg}$ / $\mathrm{kg}$ ) and enhanced SOD (10 and $30 \mathrm{mg} / \mathrm{kg}$ ) and GSHPx $(30 \mathrm{mg} / \mathrm{kg})$ activities. In addition, simvastatin $10 \mathrm{mg} / \mathrm{kg} /$ day prevented the reduction of CAT and the increased of SOD, and simvastatin 1 or $10 \mathrm{mg}$ / $\mathrm{kg}$ /day prevented the increased on GSH-Px.

Our results showed an increment in SOD and GSH-Px activities in hippocampus and cerebral cortex of rats induced by LDX administration. In this scenario, antioxidant enzymes can respond to persistently increased oxidative stress by compensatory increase in its activity through stimulation of protein synthesis, as occurs with other enzymes (de Souza et al. 2000) By the other hand, LDX administration decreased CAT activity in the hippocampus and cerebral cortex and SOD activity in the cerebellum, which might be due to the consumption of the enzymes, in an attempt to prevent oxidative stress. In addition, simvastatin showed an antioxidant action.

The mechanisms responsible for LDX-induced oxidative stress have not been fully identified. However, our data suggest that the detrimental effects of LDX in the present animal model are mediated via dopamine metabolism and oxidation. It is well known that increased extracellular dopamine may be problematic. Oxidation of dopamine can produce both superoxide and hydrogen peroxide, which may then form hydroxyl radicals in the presence of certain metals (Graham 1978). Additionally, previous studies have indicated that dopamine can become neurotoxic following its oxidation to a dopamine quinone, which may then react with cellular thiols to form 5-S-glutathionyl dopamine and 5-S-cysteinyl dopamine (Shen et al. 1997, Miyazaki and Asanuma 2008). The subsequent oxidation of 5-S-cysteinyl dopamine produces a number of neurotoxic compounds (Graham 1978). Free dopamine has also been shown to induce an inflammatory response in the brain characterized by an increase in cytokines and chemokines that lead to an induction of microgliosis (Haeman et al. 2012). Interestingly, widely used statin drugs have been shown to attenuate glial activation, inhibit oxidative stress and protect dopaminergic neurons (Kreipke and Walker 2004, Selley 2005, Wang et al. 2005, Wang et al. 2006, Ghosh et al. 2009, Rowley et al. 2012, 2014).

Studies showed that simvastatin significantly prevented dopaminergic neurons from degeneration, partially via NMDAR mediated anti-inflammatory mechanisms such as TNF- $\alpha$ or iNOS and through elevated brain derived neurotrophic factors that are found to protect neurons (Wang et al. 2005, 2006, 2011, Hernández-Romero et al. 2008, Yan et al. 2011). These neuroprotective mechanisms 
arise from the inhibition by statins of isoprenoids geranylgeranyl pyrophosphate that would in turn functionally de-activate modifications upon GTPases like Rho, Rac and cdc42 which act as molecular switches for numerous functions such as apoptosis, maintenance and rearrangement of the cytoskeleton, and cellular polarity (Ghosh et al. 2009, Kumar et al. 2012).

Our results suggest that simvastatin combined with LDX induced a significant increased locomotion and LDX administration causes an oxidative imbalance determined by an increment in lipid peroxidation, protein oxidation and alterations in the activities of antioxidant enzymes in brain areas; moreover, in the presence of simvastatin, most of these effects were prevented. We hypothesize that simvastatin will protect from LDX based on the antioxidant, anti-inflammatory and anti-excitotoxic properties exhibited by this compound that allow them to afford neuroprotection in different neurodegenerative disorders. However, further studies are necessary to evaluate whether simvastatin could be useful as a potential adjuvant for the prevention of the oxidative damage.

\section{ACKNOWLEDGMENTS}

This work was supported by grants from Universidade Regional de Blumenau (FURB), Programa Institucional de Bolsas de Iniciação Científica (PIBIC) / Conselho Nacional de Desenvolvimento Científico e Tecnológico (CNPq) and Fundação de Amparo à Pesquisa e Inovação de Santa Catarina (FAPESC).

\section{RESUMO}

$\mathrm{O}$ presente estudo tem o objetivo de investigar diretamente os efeitos comportamentais e antioxidantes da sinvastatina em um modelo de mania bipolar induzida por dimesilato de lisdexanfetamina. Ratos Wistar foram tratados durante 30 dias com simvastatina. No $24^{\circ}$ dia após o início do tratamento, foi administrada dimesilato de lisdexanfetamina durante 7 dias em cada rato. Os resultados sugerem que sinvastatina combinada com dimesilato de lisdexanfetamina induziu um aumento significativo na locomoção, e administração de dimesilato de lisdexanfetamina provoca um desequilíbrio oxidativo determinado por um aumento na peroxidação lipídica, oxidação de proteínas e alterações nas atividades de enzimas antioxidantes em áreas do cérebro; adicionalmente, na presença de sinvastatina a maioria destes efeitos foram bloqueados. Estes resultados contribuem para um melhor entendimento dos papeis críticos do tratamento dos distúrbios neuropsiquiátricos com dimesilato de lisdexanfetamina, associado com o aumento do estresse oxidativo e com alterações das enzimas antioxidantes. Tendo em vista o papel central exercido pelo dimesilato de lisdexanfetamina, o efeito antioxidante estabelecido pela terapia com sinvastatina é de grande interesse.

Palavras-chave: Anfetamina, Dimesilato de lisdexanfetamina, Estresse oxidativo, Sinvastatina.

\section{REFERENCES}

AEBI H. 1984. Catalase in vitro. Methods Enzymol 105: 121126.

ANDREAZZA AC ET AL. 2008. Effects of mood stabilizers on DNA damage in an animal model of mania. J Psychiatry Neurosci 33: 516-524.

BARONE E, DI DOMENICO F AND BUTTERFIELD DA. 2014. Statins more than cholesterol lowering agents in Alzheimer disease: their pleiotropic functions as potential therapeutic targets. Biochem Pharmacol 88: 605-616.

BATTISTI JJ, URETSKY NJ AND WALLACE LJ. 2000. NMDA glutamate receptor role in the development of contextdependent and independent sensitization of the induction of stereotypy by amphetamine or apomorphine. Behav Brain Res 114: 167-174.

BERMAN SB AND HASTINGS TG. 1999. Dopamine oxidation alters mitochondrial respiration and induces permeability transition in brain mitochondria: implications for Parkinson's disease. J Neurochem 73: 1127-1137.

Burrows KB, Gudelsky G AND YAMAMOTO BK. 2000. Rapid and transient inhibition of mitochondrial function following methamphetamine or 3,4-methylenedioxymethamphetamine administration. Eur J Pharmacol 398: 11-18.

CAdor M, BJjou Y, CAILhol S And Stinus L. 1999. D-amphetamine-induced behavioral sensitization: implication of a glutamatergic medial prefrontal cortexventral tegmental area innervation. Neuroscience 94: 705721. 
CAmargo AM, Lima DD, DAl Magro DD, SEUbert JK, CRUZ JN AND CRUZ JG. 2013. Adjuvant effects of classical music on simvastatin induced reduction of anxiety but not object recognition memory in rats. Psychol Neurosci 6: 403-410.

DAVARO F, Forde SD, GARFIELD M, JIANG Z, HALMEN K, TAMBURRo ND, KURT-JONES E, FitzGERALD KA, GOLENBOCK DT AND WANG D. 2014. 3-Hydroxyl3-methylglutaryl coenzyme A (HMG-CoA) reductase inhibitor (statin)-induced 28-kDa interleukin-1 $\beta$ interferes with mature IL-1 $\beta$ signaling. J Biol Chem 289: 1621416222.

De SouzA, Wyse AT, STRECK EL, WORM P, WAJNER A, RitTer F AND NetTo CA. 2000. Preconditioning prevents the inhibition of $\mathrm{Na}^{+}, \mathrm{K}^{+}$-ATPase activity after brain ischemia. Neurochem Res 25: 971-975.

Dietrich-Muszalska A AND KWiatKowska A. 2014. Generation of superoxide anion radicals and platelet glutathione peroxidase activity in patients with schizophrenia. Neuropsychiatr Dis Treat 10: 703-709.

FLOHÉ L AND OTTING F. 1984. Superoxide dismutase assays. Methods Enzymol 105: 93-104.

FLOYD RA. 1999. Antioxidants, oxidative stress, and degenerative neurological disorders. Proc Soc Exp Biol Med 222: 236-245.

FREY BN, VALVASSORI SS, RÉUS GZ, MARTINS MR, PETRONILHo FC, BARdini K, DAL-PIZZOL F, KAPCZINSKI F AND QUEVEDO J. 2006a. Effects of lithium and valproate on amphetamine-induced oxidative stress generation in an animal model of mania. J Psychiatry Neurosci 31: 326-332.

Frey BN, VALVASSORI SS, RÉUs GZ, MARTINS MR, PETRONILHOFC, BARDINI K, DAL-PIZZOL F, KAPCZINSKI F AND QUEVEDO J. 2006b. Changes in antioxidant defense enzymes after d-amphetamine exposure: implications as an animal model of mania. Neurochem Res 31: 699-703.

GARCIA-SOUZA LF AND OLIVEIRA MF. 2014. Mitochondria: biological roles in platelet physiology and pathology. Int $\mathrm{J}$ Biochem Cell Biol 50: 156-160.

GHOSH A, ROY A, MATRAS J, BRAHMACHARI S, GENDELMAN HE AND PAHAN K. 2009. Simvastatin inhibits the activation of $\mathrm{p} 21$ ras and prevents the loss of dopaminergic neurons in a mouse model of Parkinson's disease. J Neurosci 29: 13543-13556.

GLUCK MR, MOY LY, JAYATILlEKE E, HOGAN KA, MANZINO L AND SONSALLA PK. 2001. Parallel increases in lipid and protein oxidative markers in several mouse brain regions after methamphetamine treatment. J Neurochem 79: 152160.

GRAHAM DG. 1978. Oxidative pathways for catecholamines in the genesis of neuromelanin and cytotoxic quinones. Mol Pharmacol 14: 633-643.

HAEMAN J, DAVID B, JENNIFER M, AMAR KP, MICHELLE S, ANE K, ROBERT W AND RICHARD JS. 2012. Inflammatory effects of highly pathogenic $\mathrm{H} 5 \mathrm{~N} 1$ influenza virus infection in the CNS of mice. J Neurosci 32: 1545-1559.

HERNÁNDEZ-ROMERO MC, ARGÜELLES S, VILLARÁN RF, De Pablos RM, Delgado-Cortés MJ, SAntiago M, Herrera AJ, CANO J AND MACHAdo A. 2008. Simvastatin prevents the inflammatory process and the dopaminergic degeneration induced by the intranigral injection of lipopolysaccharide. J Neurochem 105: 445459.

KREIPKE CW AND WALKER PD. 2004. NMDA receptor blockade attenuates locomotion elicited by intrastriatal dopamine D1-receptor stimulation. Synapse 53: 28-35.

KumAR A, SHARMA N, GUPTA A, KALONIA H AND MiSHRA J. 2012. Neuroprotective potential of atorvastatin and simvastatin (HMG-CoA reductase inhibitors) against 6-hydroxydopamine (6-OHDA) induced Parkinson-like symptoms. Brain Res 1471: 13-22.

LEVINE RL, GARLAND D, OLIVER CN, AMICI A, CLIMENT I, LENZ AG, AHN BW, SHALTIEL S AND STADTMAN ER. 1990. Determination of carbonyl content in oxidatively modified proteins. Methods Enzymol 186: 464-478.

LOWRY OH, ROSEBROUGH NJ, FARR AL AND RANDALL RJ. 1951. Protein measurement with the Folin phenol reagent. J Biol Chem 193: 265-275.

MACÊDO DS ET AL. 2013. Effects of lithium on oxidative stress and behavioral alterations induced by lisdexamfetamine dimesylate: relevance as an animal model of mania. Prog Neuropsychopharmacol Biol Psychiatry 43: 230-237.

Malfitano AM, Marasco G, Proto MC, LAEzza C, Gazzerro P ANd Bifulco M. 2014. Statins in neurological disorders: an overview and update. Pharmacol Res 88: 74-83.

MATTINGLY G. 2010. Lisdexamfetamine dimesylate: a prodrug stimulant for the treatment of ADHD in children and adults. CNS Spectr 15: 315-325.

MIYAZAKI I AND ASANUMA M. 2008. Dopaminergic neuronspecific oxidative stress caused by dopamine itself. Acta Med Okayama 62: 141-150.

MOHAMMADi MT, AMINI R, JAHANBAKHSH Z AND SHEKARFOROUSH S. 2013. Effects of atorvastatin on the hypertension-induced oxidative stress in the rat brain. Iran Biomed J 17: 152-157.

MoON GJ, KIM SJ, CHO YH, RYOO S AND BANG OY. 2014. Antioxidant effects of statins in patients with atherosclerotic cerebrovascular disease. J Clin Neurol 10: 140-147.

NAJIB J. 2012. Lisdexamfetamine in the treatment of adolescents and children with attention-deficit/ hyperactivity disorder. Adolesc Health Med Ther 3: 51-66.

OHKAWA H, OHISHI N AND YAGI K. 1979. Assay for lipid peroxides in animal tissues by thiobarbituric acid reaction. Anal Biochem 95: 351-358.

REZNICK AZ AND PACKER L. 1994. Oxidative damage to proteins: spectrophotometric method for carbonyl assay. Methods Enzymol 233: 357-363. 
RIEGEL RE, VALVASSORI SS, ELIAS G, RÉUS GZ, STECKERT AV, De Souza B, Petronilho F, Gavioli EC, DalPIZZOL F AND QUEVEDO J. 2009. Animal model of mania induced by ouabain: evidence of oxidative stress in submitochondrial particles of the rat brain. Neurochem Int 55: 491-495.

Rizzo LB, Costa LG, MANSUR RB, SWARdFAGER W, BELANGERO SI, GRASSI-OLIVEIRA R, MCINTYRE RS, BAUER ME AND BRIETZKE E. 2014. The theory of bipolar disorder as an illness of accelerated aging: implications for clinical care and research. Neurosci Biobehav Rev 42: 157-169.

ROBINSON TE AND BECKER JB. 1986. Enduring changes in brain and behavior produced by chronic amphetamine administration: a review and evaluation of animal models of amphetamine psychosis. Brain Res 396: 157-198.

ROWley HL, KulKarni R, GOSDEN J, Brammer R, HACKETT D AND HEAL DJ. 2012. Lisdexamfetamine and immediate release d-amfetamine - differences in pharmacokinetic/pharmacodynamic relationships revealed by striatal microdialysis in freely-moving rats with simultaneous determination of plasma drug concentrations and locomotor activity. Neuropharmacol 63: 1064-1074.

ROWLEY HL, KulKarni RS, GOSDEN J, BRAMMER RJ, HACKETT D AND HeAL DJ. 2014. Differences in the neurochemical and behavioural profiles of lisdexamfetamine methylphenidate and modafinil revealed by simultaneous dual-probe microdialysis and locomotor activity measurements in freely-moving rats. J Psychopharmacol 28: 254-269.

SANTOS T, BAUNGRATZ MM, HASKEL SP, DE LIMA DD, DA CRUZ JN, MAGRO DD AND DA CRUZ JG. 2012. Behavioral interactions of simvastatin and fluoxetine in tests of anxiety and depression. Neuropsychiatr Dis Treat 8: 413-422.

SELLEY ML. 2005. Simvastatin prevents 1-methyl-4-phenyl1,2,3,6-tetrahydropyridine-induced striatal dopamine depletion and protein tyrosine nitration in mice. Brain Res 1037: 1-6.

SHEN XM, ZHANG F AND DRYHURST G. 1997. Oxidation of dopamine in the presence of cysteine: characterization of new toxic products. Chem Res Toxicol 10: 147-155.

SONSALLA PK, NICKLAS WJ AND HEIKKILA RE. 1989. Role for excitatory amino acids in methamphetamine-induced nigrostriatal dopaminergic toxicity. Science 243: 398-400.
STADTMAN ER AND LEVINE RL. 2003. Free radical-mediated oxidation of free amino acids and amino acid residues in proteins. Amino Acids 25: 207-218.

TEMPLE A, YEN TY AND GRONERT S. 2006. Identification of specific protein carbonylation sites in model oxidations of human serum albumin. J Am Soc Mass Spectrom 17: 1172-1180.

UEKAWA K ET AL. 2014. Rosuvastatin ameliorates early brain injury after subarachnoid hemorrhage via suppression of superoxide formation and nuclear factor-Kappa B activation in rats. J Stroke Cerebrovasc Dis 23: 1429-1439.

VANCE JE. 2012. Dysregulation of cholesterol balance in the brain: contribution to neurodegenerative diseases. Dis Model Mech 5: 746-755.

WANG Q, TANG XN, WANG L, YENARI MA, YING W, GOH BC, LEE HS, WILDER-SMITH EP AND WONG PT. 2006. Effects of high dose of simvastatin on levels of dopamine and its reuptake in prefrontal cortex and striatum among SD rats. Neurosci Lett 408: 189-193.

WANG Q, TING WL, YANG H AND WONG PT. 2005. High doses of simvastatin upregulate dopamine D1 and D2 receptor expression in the rat prefrontal cortex: possible involvement of endothelial nitric oxide synthase. Br J Pharmacol 144: 933-939.

WANG Q, YAN J, CHEN X, LI J, YANG Y, WENG J, DENG C AND YENARI MA. 2011. Statins: multiple neuroprotective mechanisms in neurodegenerative diseases. Exp Neurol 230: 27-34.

WANG Q, ZENGIN A, DENG C, LI Y, NEWELl KA, YANG GY, LU Y, WILDER-SMITH EP, ZHAO H AND HUANG XF. 2009. High dose of simvastatin induces hyperlocomotive and anxiolytic-like activities: The association with the upregulation of NMDA receptor binding in the rat brain. Exp Neurol 216: 132-138.

WENDEL A. 1981. Glutathione peroxidase. Methods Enzymol 77: 325-333.

WOLF ME, DAHLIN SL, HU XT, XUE CJ AND WHITE K. 1995. Effects of lesions of prefrontal cortex, amygdala, or fornix on behavioral sensitization to amphetamine: comparison with N-methyl-D-aspartate antagonists. Neuroscience 69: 417-439.

YAN J ET AL. 2011. Simvastatin prevents dopaminergic neurodegeneration in experimental Parkinsonian models: the association with anti-inflammatory responses. PLoS One 6: e20945-e20945. 